\title{
ANALISIS TEKS DAN KONTEKS TEKS DRAMA KARYA SISWA SEKOLAH MENENGAH ATAS
}

\author{
Hari Agus Sasongko, Nugraheni Eko Wardani, Raheni Suhita \\ Universitas Sebelas Maret \\ Email: hariagussasongko@student.uns.ac.id
}

\begin{abstract}
Abstrak: Penelitian yang digunakan dalam penelitian ini adalah penelitian analisis isi dengan pendekatan kualitatif. Data yang digunakan diambil dengan metode purposive sampling. Untuk menguji keabsahan/validitas data dalam penelitian ini menggunakan teknik triangulasi sumber, dan triangulasi teori. Hasil dari penelitian ini adalah 179 data pengacuan, 23 data penyulihan, dan 60 data perangkaian. Adapun peneliti menemukan tiga buah data pengacuan, yaitu pengacuan persona, demonstratif, dan komparatif. Adapun perinciannya sebagai berikut: terdapat 122 data pengacuan persona, 41 data pengacuan demontratif, dan 16 pengacuan komparatif. Dalam teks drama karya siswa kelas XI SMA Negeri 1 Sukoharjo ditemukan juga aspek leksikal. Aspek leksikal yang ditemukan antara lain: (1) repetisi, (2) sinonimi, (3) antonimi, dan (4) kolokasi. Perinciannya adalah sebagai berikut: 37 data repetisi, 6 data sinonimi, 12 data antonimi, dan 16 data kolokasi. Dalam penelitian ini terdapat empat prinsip yang menjadi acuan dalam analisis kontekstual teks drama, yaitu: 1) prinsip penafsiran personal, 2) prinsip penafsiran lokasional, 3) prinsip penafsiran temporal, dan 4) prinsip analogi. Berdasarkan hal tersebut, dapat diketahui bahwa terdapat unsur konteksual dalam kumpulan teks drama karya siswa kelas XI SMA Negeri 1 Sukoharjo. Naskah teks drama karya siswa SMA Negeri 1 Sukoharjo terdapat aspek tekstual, yaitu leksikal dan gramatikal. Terdapat empat prinsip yang menjadi acuan dalam analisis kontekstual teks drama, yaitu prinsip penafsiran personal, prinsip penafsiran lokasional, prinsip penafsiran temporal, dan prinsip analogi.
\end{abstract}

Kata kunci: tekstual, kontekstual, teks drama, sekolah menengah atas

\section{ANALYSIS OF TEXT AND CONTEXT ON DRAMA WORKS BY SENIOR HIGH SCHOOL STUDENTS}

\begin{abstract}
The research used in this study is analysis of the content analyses with a qualitative approach. The Data used is taken by the purposive sampling method. To test the validity/validity of data in this study using the source triangulation techniques, and triangulation theory. The results of the study were 179 reference data, 2360 data for the The researchers found three reference data, i.e. persona, demonstrative, and comparative references. The details are as follows: There are 122 data-refering personas, 41 demonstration reference data, and 16 comparative refering. In the drama text by the class XI SMA Negeri 1 Sukoharjo also found a lexical aspect. The lexical aspects found are: (1) Reps, (2) Sinonimi, (3) Antonimi, and (4) collocations. Details are as follows: 37 data reps, 6 data Sinonimi, 12 data Antonimi, and 16 colocation data. In this study there were four principles that became a reference in the contextual analysis of the drama text, namely: 1) The principle of personal interpretation, 2) The principle of locational interpretation, 3) The principle of temporal interpretation, and 4) the principle of analogy. Based on this, it can be noted that there is a conjugual element in the collection of drama text by the students of the class XI SMA Negeri 1 Sukoharjo. The manuscript of a drama text by SMA Negeri 1 Sukoharjo is a textual aspect, lexical and grammatically. There are four principles that are referenced in the contextual analysis of the drama text, i.e. personal interpretation principles, locational interpretation principles, temporal interpretation principles, and analogy principles.
\end{abstract}

Keywords: textual, contextual, drama's text, senior high school

BASASTRA Jurnal Bahasa, Sastra, dan Pengajarannya

Volume 8 Nomor 1, April 2020, P-ISSN 2302-6405, E-ISSN 2714-9765 


\section{PENDAHULUAN}

Salah satu kompetensi dasar bahasa Salah satu kompetensi dasar bahasa Indonesia yang terdapat pada pelajaran SMA di kurikulum 2013 adalah memproduksi teks drama yang koheren sesuai dengan karakteristik teks yang akan dibuat baik secara lisan maupun tulisan. Sumarlam (2003:17) menyatakan bahwa wacana drama adalah wacana yang disampaikan dalam bentuk drama, dalam bentuk dialog, baik berupa wacana tulis maupun wacana lisan. Bentuk drama tulis terdapat pada naskah drama atau naskah sandiwara, sedangkan bentuk wacana drama lisan terdapat pada pemakaian bahasa dalam peristiwa pementasan drama, yakni percakapan antarpelaku dalam drama tersebut. Teks drama siswa merupakan salah satu karya siswa yang dijadikan media pembelajaran yang efektif bagi siswa. Selain sebagai media pembelajaran, siswa juga mampu melihat letak kesalahan mereka dalam proses menyusun naskah drama, baik secara kebahasaan maupun konflik dalam teks tersebut. Literasi sebenarnya adalah kemampuan intelektual yang digunakan untuk mengakses informasi melalui kegiatan membaca, menulis, dan berbicara (Antasari, 2017: 5).

Di SMA Negeri 1 Sukoharjo terdapat beberapa teks karya siswa yang menjadi objek penelitian bagi peneliti. Berdasarkan hasil wawancara dengan pengampu bahasa Indonesia di SMA Negeri 1 Sukoharjo dalam teks karya siswa masih terdapat ide-ide dari siswa yang masih terpengaruh dengan berbagai hal yang dilihatnya sehari-hari, contohnya dari sinetron atau film kartun. Jalan cerita dari teks drama karya siswa masih terpengaruh dari konflik-konflik yang mereka lihat dari acara-acara tersebut. Selain itu, teks drama yang dibuat oleh siswa masih memiliki kekurangan dalam hal referensi dan pengalaman menulis.

Menurut salah satu pengajar mata pelajaran Bahasa Indonesia, teks karya siswa memilki konflik yang kurang relevan dengan kehidupan mereka sehari-hari sehingga terlalu dibuat-buat, bahkan ada yang kurang pantas untuk dituliskan. Teks drama karya siswa di SMA Negeri 1 Sukoharjo masih terpengaruh pada hal-hal yang lebih menarik minat mereka seperti film kartun, novel, dan lain-lain. Menurut narasumber, teks drama karya siswa SMA Negeri 1 Sukoharjo memiliki konflik yang beraneka ragam. Konflik tersebut terkait dengan konflik-konlik yangmereka lihat dan rasakan berupa percintaan, perkelahian, bahkan dominasi terhadap satu pihak. Ada pula yang memiliki konflik dengan keluarga seperti pecahnya rumah tangga, kasih ibu, dan lain-lain. Konflik yang beraneka ragam tersebut memberikan suatu keunikan yang menggambarkan sifat, kegemaran, dan latar belakang dari siswa selaku penulis naskah drama.

Menurut Waluyo (2006:7) teks drama merupakan sastra lakon. Teks drama dibangun oleh struktur fisik berupa berupa kebahasaan, dan struktur batin berupa semantik dan makna. Sebagai salah satu karya sastra, teks drama juga harus tunduk pada konvensi sastra, dengan kata lain teks drama juga harus mengikuti kaidah dan struktur kebahasaan. Menurut Chaer (2002:156) naskah drama adalah karangan yang berisi cerita, dialog yang diucapkan para tokoh dan keadaan panggung yang diperlukan juga sikap pelaku saat pentas. Naskah drama ditulis dengan selengkaplengkapnya, bukan saja berisi keterangan atau petunjuk. Selain itu, naskah drama merupakan jalinan cerita (plot) drama, plot merupakan kerangka cerita dari awal hingga akhir. Berdasarkan hal tersebut, teks drama karya siswa SMA Negeri 1 Sukoharjo memiliki hal yang menarik dikaji, yaitu dari sisi tekstual dan kontekstual. Menurut Wijana (2011:73) mengatakan bahwa analisis tekstual merupakan bentuk bahasa, bukan hanya kata-kata yang tercetak dilembar kertas, tetapi juga semua jenis ekspresi komunikasi, ucapan, musik, gambar, efek suara, citra, dan sebagainya. Ini didukung dengan pendapat dari Djajasudarma 
(2012:12) menyatakan bahwa wacana tekstual erat kaitannya dengan pemaknaan dan sifatnya. Ada wacana yang mementingkan isi komunikasi, ada pula yang bersifat interaksional, yaitu lebih mementingkan timbal balik. Sedangkan analisis kontekstual adalah memasukkan semua situasi dan hal yang berada di luar teks dan mempengaruhi pemakaian bahasa, seperti partisipan dalam bahasa, situasi di mana teks tersebut diproduksi, fungsi yang dimaksudkan, dan sebagainya. Analisis wacana tekstual dan kontekstual dalam penulisan ini berupaya untuk menguraikan atau menginterpretasikan ujaran pencipta dan penikmat yang menghubungkannya dengan konteks terjadinya atau diucapkannya ujaran penutur tersebut, orang-orang yang terlibat dalam interaksi, pengetahuan mereka, kebiasaan, dan adat istiadat yang berlaku di tempat kejadian (Kartomiharjo dalam Wijana, 2011:74).

Teks drama karya siswa SMA Negeri 1 Sukoharjo memiliki aspek tekstual dan kontekstual yang beraneka ragam. Menurut narasumber, teks drama karya siswa mengandung aspek tekstual dan kontekstual yang beragam karena dipengaruhi konflik yang bervariasi, sehingga mempengaruhi aspek tekstual dan kontekstual dalam teks tersebut. Aspek tekstual yang beraneka ragam tersebut meliputi dialog, alur cerita, setting, penokohan, dan amanat. Dengan kata lain, aspek tekstual dalam teks drama karya siswa merupakan aspek yang hanya ditemukan dengan cara mengkaji teks drama yang telah dibaca dan dipahami sebelumnya. Adapun aspek kontekstual dalam teks drama karya siswa SMA Negeri 1 Sukoharjo meliputi kondisi ketika teks drama tersebut ditulis, kepengarangan, dan nilai-nilai yang bisa diambil dari cerita. Aspek kontekstual dalam teks drama karya siswa ditemukan melalui proses menganalisis berbagai faktor eksternal yang memengaruhi penyusunan teks drama. Contohnya adalah melalui wawancara dengan penulis.
Oleh karena itu, penelitian ini mencoba memunculkan kembali aspek tekstual dan kontekstual dari teks drama. Teks drama yang dipilih adalah teks drama karya siswa. Teks drama karya siswa patut untuk analisis untuk membantu siswa mengetahui kualitas teks drama yang dihasilkan oleh siswa, sehingga dapat menjadi tolok ukur untuk pembuatan teks drama. Hal ini sesuai dengan kompetensi dasar memproduksi teks drama yang koheren sesuai dengan karakteristik teks yang akan dibuat baik secara lisan maupun tulisan. Maksud sebenarnya dari penulis menyusun penelitian ini agar siswa dan guru mengetahui kualitas teks drama karya siswa, sehingga bila ada kekurangan dapat menjadi evaluasi untuk menghasilkan teks drama karya siswa yang berkualitas untuk ke depannya. Selain itu, dengan melakukan identifikasi dan pengajaran tentang struktur tekstual dan kontekstual dalam suatu teks drama. Siswa akan mampu menentukan dan menghasilkan intrinsik dan ekstrinsik, membuat, dan mementaskan teks drama.

Menurut Eni Winarsih (2014:54) pembahasan dalam penelitian ini menggunakan tigapembahasan antara lain (1) analisis tekstual yang meliputi kohesi gramatikal dan leksikal, (2) analisis kontekstual yang ditemukan dalam konteks situasi dan budaya.

\section{METODE PENELITIAN}

Penelitian ini merupakan penelitian yang menganalisis data berupa dokumen, yaitu data dari dialog-dialog yang terdapat dalam naskah drama karya siswa kelas XI SMA Negeri 1 Sukoharjo sebagai objek kajiannya. Penelitian ini dilakukan selama 5 bulan. Penelitian ini merupakan penelitian kualitatif dengan menggunakan pendekatan deskriptif. Pendekatan deskriptif berarti bahwa peneliti berusaha menggambarkan kegiatan penelitian yang dilakukan pada objek tertentu seara jelas dan sistematis (Sukardi, 2008:14). Sumber data primer yang digunakan dalam penelitian ini adalah dokumen yaitu naskah drama karya siswa

BASASTRA Jurnal Bahasa, Sastra, dan Pengajarannya

Volume 8 Nomor 1, April 2020, P-ISSN 2302-6405, E-ISSN 2714-9765 
di SMA Negeri 1 Sukoharjo, sedangkan sumber data sekunder berupa buku dan jurnal yang membahas mengenai analisis wacana. Teknik pengambilan sampel yang digunakan dalam penelitian ini adalah teknik purposive sampling.

\section{HASIL DAN PEMBAHASAN}

\section{Analisis Tekstual dalam Kumpulan Naskah Drama Karya Siswa}

Struktur tekstual wacana dapat dibagi ke dalam dua aspek, yaitu aspek gramatikal dan aspek leksikal. Aspek gramatikal dalam analisis tekstual meliputi:(1) pengacuan (reference), (2) penyulihan (substitution), (3) pelesapan (ellipsis), dan (4) perangkaian (conjunction). Adapun aspek leksikal dalam analisis tekstual meliputi repetisi (1) (pengulangan), (2) sinonimi (padan kata), (3) antonimi (lawan kata), (4) kolokasi (sanding kata), (5) hiponimi (hubungan atas-bawah), dan (6) ekuivalensi (kesepadanan).

Dalam naskah teks drama karya siswa SMA Negeri 1 Sukoharjo terdapat beberapa data yang terkait dengan analisis gramatikal dalam suatu teks drama. Periniciannya adalah sebagai berikut: 179 data pengacuan, 23 data penyulihan, dan 60 data perangkaian. Adapun peneliti menemukan tiga buah data pengacuan, yaitu pengacuan persona, demonstratif, dan komparatif. Adapun perinciannya sebagai berikut: terdapat 122 data pengacuan persona, 41 data pengacuan demontratif, dan 16 pengacuan komparatif.

Aspek gramatikal yang ditemukan berikutnya adalah data penyulihan. Dalam penelitian ini, data penyulihan yang ditemukan adalah 23 data. Data penyulihan yang dominan pada penelitian ini adalah data yang mengganti satu satuan lingual dengan satuan lingual lain berupa kata ataupun frasa.

Aspek berikutnya yang ditemukan adalah data perangkaian. Peneliti menemukan terdapat 60 data perangkaian yang terdapat pada teks drama karya siswa.
Perangkaian tersebut berfungsi sebaagi konjungsi yang menghubungkan frasa ataupun kalimat dalam teks. Dalam kumpulan teks drama karya siswa SMA Negeri 1 Sukoharjo ditemukan banyak perangkaian yang berfungsi konjungsi antar kalimat.

Dalam teks drama karya siswa kelas XI SMA Negeri 1 Sukoharjo ditemukan juga aspek leksikal. Aspek leksikal yang ditemukan antara lain: (1) repetisi, (2) sinonimi, (3) antonimi, dan (4) kolokasi. Perinciannya adalah sebagai berikut: 37 data repetisi, 6 data sinonimi, 12 data antonimi, dan 16 data kolokasi.

Data repetisi yang ditemukan dalam teks drama karya siswa kelas XI SMA Negeri 1 Sukoharjo merupakan pengulangan satuan lingual berupa kata, frasa, atau klausa yang berfungsi memberikan suatu penekanan sebuah konteks yang sesuai. Penekanan tersebut berfungsi untuk meberikan efek penekanan suatu makna yang mengacu ada suatu hal tertentu.

Aspek leksikal lain yang ditemukan adalah sinonimi. Dalam teks drama karya siswa kelas XI SMA Negeri 1 Sukoharjo, sinonimi yang ditemukan sebanyak 6 data. Sinonimi yang ditemukan merupakan padanan kata yang menjalin hubungan makna yang sepadan antara satu lingual dengan lingual yang lain.

Aspek berikutnya adalah antonimi. Dalam teks drama karya siswa kelas XI SMA Negeri 1 Sukoharjo ditemukan antonimi sebanyak 12 data. Antonimi yang ditemukan dalam teks ini memilki makna yang berlawanan dengan padanan kata yang lainnya. Keberlawanan makna dalam teks drama siswa SMA Negeri 1 Sukoharjo mengacu pada konteks dan posisi suatu kata atau frasa dalam kalimat.

Aspek terakhir yang ditemukan adalah kolokasi. Kolokasi yang ditemukan dalam teks drama sebanyak 16 data. Kolokasi dalam penelitian ini mengacu pada padanan kata yang membentuk makna baru. 
Dari keseluruhan aspek gramatikal dan leksikal yang ditemukan dalam teks drama karya siswa kelas XI SMA Negeri 1 Sukoharjo maka dapat disimpulkan bahwa semua teks drama karya tersebut merupakan wacana yang utuh. Hal ini dikarenakan dalam naskah tersebut sudah mencakup aspek gramatikal dan leksikal.

Penelitian ini memiliki perbedaan dengan penelitian yang dilakukan oleh Feng Li (2010) yang berjudul "Textual Analysis Of Corporate Disclosures: A Survey Of the Literature". Penelitian tersebut membahas tentang kajian tekstual dari teks dari sebuah korporasi akuntan, sedangkan penelitian ini mengkaji aspek testual dari teks drama karya siswa.

\section{Analisis Kontekstual dalam Kumpulan Naskah Drama Karya Siswa}

Dalam wacana teks drama karya siswa kelas XI SMA Negeri 1 Sukoharjo terdapat kajian kontekstual yang menjadi objek pada penelitian ini. Analisis wacana kontekstual ini berupaya untuk menguraikan atau menginterpretasikan ujaran pencipta dan penikmat yang menghubungkannya dengan konteks tempat terjadinya atau diucapkannya ujaran penutur tersebut, orang-orang yang terlibat dalam interaksi, pengetahuan umum mereka, kebiasaan, dan adat istiadat yang berlaku di tempat tersebut atau di tempat lainnya. Dalam penelitian ini terdapat empat prinsip yang menjadi acuan dalam analisis kontekstual teks drama, yaitu: 1) prinsip penafsiran personal, 2) prinsip penafsiran lokasional, 3) prinsip penafsiran temporal, dan 4) prinsip analogi.

Prinsip penafsiran personal dalam teks drama karya siswa kelas XI SMA Negeri 1 Sukoharjo mengacu pada pelaku atau pelibat pada wacana tersebut. Dalam hal ini, keberadaan penutur dan mitra tutur menjadi sangat penting. Dalam naskah Isa Bella pelibat yang menjadi penutur adalah tokoh Isa dan Bella sebagai karakter utama, sedangkan mitra tuturnya adalah Nenek, Ayah, dan Ibu angkat Bella.Dalam naskah Jangan Mendekat pelibat yang menjadi penutur adalah tokoh Andi sebagai karakter utama, sedangkan mitra tuturnya adalah Nenek, Kakek, Ayah Andi, Pak Polisi, Orang gila, dan teman-teman Andi.Pelibat wacana dalam naskah drama Buas hanya ditujukan pada tokoh utama sebagai penutur, yaitu Nate dan sebagai mitra tuturnya adalah Alois, Sebastian, Historia, Ciel, dan Pak Levi.

Prinsip penafsiran lokasional berkaitan dengan tempat terjadinya lokasi dalam naskah drama dan berperan untuk lebih memahami isi dari teks drama. Tempat terjadinya cerita dalam naskah Isa Bella adalah di Pantai, di rumah Isa, dan di rumah Bella. Tempat terjadinya cerita dalam naskah Jangan Mendekat adalah di rumah Andi, jalan Kampung Kantil, rumah Pak RW, rumah kosong, dan kantor polisi. Lokasi atau tempat terjadinya situasi pada konteks wacana naskah drama Buas berlangsung pada beberapa tempat yang berkaitan, yaitu di kelas, toilet, dan belakang gedung.

Prinsip penafsiran temporal merupakan prinsip yang berkaitan dengan waktu yang terkait dengan terjadinya peristiwa dalam naskah drama. Pada naskah Isa Bella, peristiwa di dalamnya memiliki alur campuran, dikarenakan antara adegan di babak 1 dan babak-babak selanjutnya kurang berkesinambungan. Namun, naskah ini dengan jelas menceritakan waktu terjadinya peristiwa dalam naskah. Dalam narasi yang diceritakan narator, dapat diketahui bahwa peristiwa tersebut terjadi pada waktu siang dan petang hari. Isi ceita pada naskah Jangan Mendekat dengan jelas menceritakan waktu terjadinya peristiwa dalam naskah. Dalam narasi yang diceritakan narator, dapat diketahui bahwa peristiwa tersebut terjadi pada waktu pagi dan malam hari. Pada naskah drama Buas merupakan peristiwa-peristiwa yang terjadi secara linear (progresif), rapat, dan berurutan. Naskah ini dengan jelas menceritakan waktu terjadinya peristiwa 
dalam naskah, yaitu pagi hari dan siang hari.

Prinsip analogi digunakan sebagai dasar oleh penutur maupun mitra tutur dalam memahami makna dan mengidentifikasi maksud dari (bagian atau keseluruhan) sebuah wacana. Pokok permasalahan dalam naskah Isa Bella adalah adanya dua saudara, yaitu Isa dan Bella yang terpisah karena adanya bencana alam. Pokok permasalahan dalam naskah Jangan mendekat adalah adanya konflik kemunculan hantu yang menakuti warga kampung Kantil dan berhasil dipecahkan oleh tokoh utama, yaitu Andi dan temantemannya.. Pokok permasalahan dalam naskah Buas adalah adanya dua orang teman sekelas, yaitu Nate dan Alois yang terlibat konflik saling menjatuhkan satu dengan yang lain.

Berdasarkan hal tersebut, dapat diketahui bahwa terdapat unsur konteksual dalam kumpulan teks drama karya siswa kelas XI SMA Negeri 1 Sukoharjo. Unsur kontekstual dalam naskah drama merupakan salah satu unsur pembangun dalam suatu naskah.

Penelitian ini memiliki persamaan dengan hasil penelitian Ariningsih, Sumarwati, dan Saddhono (2012 dalam perbedaan dengan penelitian yang

\section{REFERENSI}

Antasari, W.I. (2017). Implementasi Gerakan Literasi Sekolah Tahap Pembiasaan di MI Muhammadiyah Gendatapa Sumbang Banyumas. Jurnal Libria, 9 (1), 13-24.

Chaer, A. (2002). Terampil Bermain Drama. Jakarta: Grasindo.

Djajasudarma, F. (2012). Wacana dan Pragmatik. Bandung: Refika Aditama.

Harras, K.A. (2011). Mengembangkan Potensi Anak melalui Program Literasi Keluarga. Jurnal Artikulasi, 10 (1).

Keraf, G. (2007). Diksi dan Gaya Bahasa. Jakarta: Gramedia. dilakukan oleh Donald Mc Tavish dan Ellen B. Piro (2010) yang berjudul "Contextual Content Analysis". Penelitian tersebut hanya mengkaji pendekatan kontekstual dari beberapa ujaran lisan yang ada dalam masyarakat, sedangkan penelitian ini mengkaji tentang ujaran yang ada pada teks drama karya siswa. Selain itu, ditemukan pula persamaan dari penelitian ini, yaitu sama-sama mengkaji aspek kontekstual dari suatu ujaran.

\section{SIMPULAN}

Dalam naskah teks drama karya siswa SMA Negeri 1 Sukoharjo terdapat beberapa data yang terkait dengan analisis gramatikal dalam suatu teks drama. Periniciannya adalah sebagai berikut: 179 data pengacuan, 23 data penyulihan, dan 60 data perangkaian. Dalam penelitian ini terdapat empat prinsip yang menjadi acuan dalam analisis kontekstual teks drama, yaitu: 1) prinsip penafsiran personal, 2) prinsip penafsiran lokasional, 3) prinsip penafsiran temporal, dan 4) prinsip analogi. Berdasarkan hal tersebut, dapat diketahui bahwa terdapat unsur konteksual dalam kumpulan teks drama karya siswa kelas XI SMA Negeri 1 Sukoharjo.

Lestari, G. (2015). Bhinnekha Tunggal Ika: Khasanah Multikultural Indonesia di Tengah Kehidupan Sara. Jurnal Pendidikan Pancasila dan Kewarganegaraan, 28 (1), 31-37.

Oktavia, W. \& Zuliyandari, D. (2019). Analisis Wacana Tekstual dan Kontekstual dalam Naskah Drama Bunga Rumah Makan Karya Utuy Tatang Sontani. Jurnal Lingua, Vol 15 (2), 223-233.

Satoto, S. (2012). Analisis Drama dan Teater Bagian 1. Yogyakarta: Penerbit Ombak. 
Sukardi. (2008). Metodologi Penelitian Pendidikan: Kompetensi dan Praktiknya. Jakarta: Bumi Aksara.

Sumarlam. (2003). Teori dan Praktek Analisis Wacana. Surakarta: Pustaka Cakra.

Waluyo, H.J. (2003). Drama: Teori dan Pengajarannya. Yogyakarta: Hanindita Graha Widya. . (2006). Drama Naskah, Pengajaran, dan Pementasannya. Surakarta: UNS Press

Wijana, I.D.P., \& Muhammad Rohmadi. (2008). Semantik Teori dan Analisis. Surakarta: Yuma Pustaka. - (2011). Analisis Wacana Pragmatik: Kajian Teori dan Analisis. Surakarta: Yuma Pustaka.

Winarsih, E. (2014). Analisis Wacana Tekstual dan Kontekstual dalam Spanduk Iklan Partai Politik dan Calon Anggota Legislatif Tahun 2014 di Kabupaten Madiun. Jurnal Widyabastra 2(1), 50-61. 